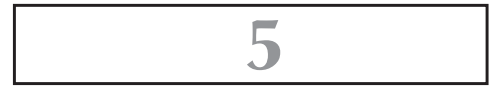

\title{
SISTEMA NORMATIVO DA DÍVIDA PÚBLICA NO BRASIL
}

\section{Paulo Cezar Neves Junior}

Doutorando pela Universidade de São Paulo. Mestre pela PUC/SP. Especialização na Universidade Federal de Santa Catarina. Pós-graduado em Direitos Fundamentais pela Faculdade de Direito da Universidade de Coimbra - Portugal. Graduado em Direito pela Universidade de São Paulo. Foi Técnico Judiciário, Analista Judiciário e Defensor Público Federal. Juiz Federal Diretor do Foro da Seção Judiciária de São Paulo (2016-2018). Atualmente é Juiz Federal

em São Paulo/SP e Professor de Direito Financeiro

e Processual Civil no Curso FMB.

\section{SUMÁRIO}

Introdução - 1. Dívida pública - 2. A Constituição Federal e a dívida pública-3. Leis complementares e a dívida pública -4. Leis ordinárias - 5. Normas infralegais - Conclusões - Referências. 


\section{INTRODUÇÃO}

Mesmo envolvendo vultosas quantias e uma preocupante evolução na história de nosso país ${ }^{1}$, a dívida pública é um dos temas mais complexos e pouco estudados do Direito Financeiro no Brasil.

No entanto, o conhecimento, a transparência e o regramento da dívida pública são extremamente relevantes para a eficiência do gasto governamental, para o controle da Administração Pública e para o próprio desenvolvimento econômico do país.

Diante disso, o presente estudo busca apresentar uma análise da estrutura normativa a que está submetida a dívida pública em nosso ordenamento jurídico como forma de contribuir para o aprofundamento dos conhecimentos a respeito no Brasil.

Afinal, a falta de conhecimento e de um tratamento legislativo sistematizado e adequado da dívida pública em nosso país tem provocado uma série de problemas que assim podem ser sintetizados: a) impossibilidade de um controle social efetivo da atividade financeira do Estado; b) endividamento cada vez mais elevado dos entes públicos, que se utilizam de manobras orçamentárias para se afastarem das limitações legais impostas a tais atividades; c) prejuízos a uma melhor distribuição dos recursos financeiros do Estado normalmente em detrimento da população mais carente; d) a ausência de regramento vem sendo substituída por excessiva regulamentação expedida pelo Banco Central do Brasil (BACEN), disciplinando a realização de operações com títulos públicos no mercado aberto, que tem como principal objetivo assegurar liquidez, a qualquer momento, para as aplicações da espécie; e e) o BACEN foi criando restrições operacionais para as instituições que operam no "open-market” na negociação desses papéis, principalmente quanto à garantia de liquidez, o que passou a dificultar o alongamento do perfil de prazo das aplicações e, como consequência, da própria dívida.

Para alcançarmos nossos objetivos, partindo de uma análise constitucional, passaremos a identificar as principais normas que tratam da dívida pública em nosso país, buscando estruturar, ao final, o sistema normativo que rege a matéria.

1 "A dívida bruta do setor público consolidado avançou de R \$ 4,450 trilhões em fevereiro para R \$ 4,527 trilhões um mês depois. Em relação ao Produto Interno Bruto (PIB), a dívida passou de $70,6 \%$ para $71,6 \%$ do PIB, novo recorde. A previsão do Banco Central (BC) era de alta para 71,1\%. Para 2017, a projeção é de 76,2\% do PIB” (disponível em www.valor.com.br/ brasil/4951974/divida-bruta-do-setor-publico-bate-716-do-pib-e-tem-novo-record. Verificado em 14/10/2017). 
Com isso, acredita-se estar contribuindo para uma melhor compreensão desta importante atividade financeira do Estado.

\section{DÍVIDA PÚBLICA}

A dificuldade para a compreensão da dívida pública começa já na utilização da própria expressão.

Em várias passagens, observamos o uso das expressões "crédito público", "empréstimo público" e "dívida pública” como sinônimas², mas precisamos fazer as devidas distinções para estabelecermos os limites necessários à compreensão mais exata das normas aplicáveis à dívida pública em nosso país.

Kiyoshi Harada diz que "dívida pública nada mais é do que o volume de recursos financeiros obtidos por um ente público, dentro de um determinado período, sob condição de devolver, em geral, acrescido de juros, e dentro de certo prazo estabelecido"3.

Como se vê, essa definição de Harada aparenta colocar a dívida pública como sinônimo de empréstimo público.

Já para José Mauricio Conti, dívida pública "compreende o conjunto de obrigações de natureza financeira assumidas pelo Poder Público".

$\mathrm{Na}$ verdade, como em toda Ciência, devemos ter também no Direito uma precisão no uso das expressões a fim de evitarmos confusões técnicas.

Assim, seguindo o que se utiliza no âmbito do Direito Privado, em especial no estudo das Obrigações, a distinção entre crédito, empréstimo e dívida também deve ser feita no Direito Público e, neste ponto, é mister que o Direito Financeiro passe a ter mais precisão no uso das expressões mencionadas.

2 O próprio sítio do Ministério do Planejamento usa a expressão com esse indicativo de sinônimo de empréstimo público. Confira: "Dívida pública é a dívida contraída pelo governo com entidades financeiras ou pessoas da sociedade para financiar parte de seus gastos que não são cobertos com a arrecadação de impostos ou alcançar alguns objetivos de gestão econômica, tais como controlar o nível de atividade, o crédito e o consumo ou, ainda, captar dólares no exterior. A dívida pública se subdivide em dívida interna e dívida externa. Os principais credores do setor público são, normalmente, bancos públicos e privados que operam no País, investidores privados, instituições financeiras internacionais e governos de outros países" (In: http://www.planejamento.gov.br/servicos/faq/orcamento-da-uniao/conceitos-sobre-orcamento/o-que-e-divida-publica. Verificado em 20/10/2017).

3 “Responsabilidade Fiscal”. São Paulo: Juarez de Oliveira, 202, p. 134.

4 “Direito Financeiro na Constituição de 1988”. São Paulo: Oliveira Mendes, 1988, p. 70. 
Nesse passo, Cesar Andrade faz interessante estudo apontando para o caminho a ser seguido nesta área do Direito ${ }^{5}$. Assim, sintetizando as ideias de Andrade, podemos dizer que crédito público está relacionado à "ideia de confiança ou fé de que determinada pessoa cumprirá seus deveres e obrigações, bem como de que esta pessoa possui os meios econômicos ou capitais disponíveis para tanto"6. Dessa maneira, crédito público é uma aptidão política, econômica, jurídica e moral de um ente público para obter empréstimos. Por sua vez, empréstimo público, nas palavras de Regis Fernandes de Oliveira, é "o contrato administrativo pelo qual o Estado recebe determinado valor que se obriga a pagar, na forma por ele estipulada"7. Finalmente, dívida pública, pode ser definida como o conjunto de obrigações financeiras nas quais o ente público ocupa o polo passivo ${ }^{8}$. Eventuais restrições a esta definição doutrinária mais ampla podem existir, dependendo de limitações feitas pelo doutrinador ou pelo legislador, como, por exemplo, quando se fala em dívida pública externa (obrigação contraída com credor estrangeiro art. 163, II, da Constituição Federal) e dívida pública consolidada (art. 52, VI, da Constituição Federal).

Dívida pública como sinônimo de conjunto de obrigações do ente público é o sentido que utilizaremos neste trabalho para análise do regramento jurídico da dívida pública brasileira. Assim, não somente as obrigações decorrentes de empréstimo público integram-na, mas também as oriundas de oferta de títulos públicos, restos a pagar ainda não quitados, precatórios etc.

Partindo desta definição, passamos a analisar o arcabouço normativo existente em nosso ordenamento jurídico, começando pela Constituição Federal.

\section{A CONSTITUIÇÃO FEDERAL E A DÍVIDA PÚBLICA}

De pronto, não é demais lembrar que, tratando-se de atividade do Estado, contrair dívida pública é conduta que deve sempre observar os princípios da Ad-

5 ANDRADE, Cesar Augusto Seijas de. "O Controle do Endividamento Público e a Autonomia dos Entes da Federação”. Dissertação (Mestrado em Direito Econômico e Financeiro). Faculdade de Direito, Universidade de São Paulo, São Paulo, 2012.

6 Idem. Ibidem, p. 20

7 "Curso de Direito Financeiro". São Paulo: Editora Revista dos Tribunais, 2006, p. 581.

8 Alguns doutrinadores, como Ricardo Lobo Torres, entendem de forma diferente. Nas palavras de Torres, o conceito de dívida pública no Direito Financeiro seria diferente porque abrangeria apenas "os empréstimos captados no mercado financeiro interno e externo, através de contratos assinados com os bancos e instituições financeiras ou do oferecimento de títulos ao público em geral. Estende-se, ainda, à concessão de garantias e avais, que potencialmente podem gerar endividamento" (“Curso de Direito Financeiro e Tributário”. Rio de Janeiro: Renovar, 14ª ed., 2007, p. 217). 
ministração Pública elencados essencialmente no art. 37 da Constituição Federal, ou seja, os princípios da legalidade, impessoalidade, moralidade, publicidade e eficiência.

No mais, como alicerce do sistema normativo da dívida pública, a Constituição Federal define a competência legislativa para tratar da matéria, determinando competir ao Congresso Nacional dispor a respeito dela (art. 48, II), bem como sobre o "montante da dívida mobiliária federal” (art. 48, XIV).

Ademais, compete privativamente ao Senado Federal tratar de temas sensíveis relacionados à dívida pública, devendo (art. 52, V a IX):

1) autorizar operações externas de natureza financeira, de interesse da União, dos Estados, do Distrito Federal, dos Territórios e dos Municípios;

2) fixar, por proposta do Presidente da República, limites globais para o montante da dívida consolidada da União, dos Estados, do Distrito Federal e dos Municípios;

3) dispor sobre limites globais e condições para as operações de crédito externo e interno da União, dos Estados, do Distrito Federal e dos Municípios, de suas autarquias e demais entidades controladas pelo Poder Público federal;

4) dispor sobre limites e condições para a concessão de garantia da União em operações de crédito externo e interno;

5) estabelecer limites globais e condições para o montante da dívida mobiliária dos Estados, do Distrito Federal e dos Municípios.

Mas a Constituição Federal vai além de definir regras de competência a respeito da dívida pública, estabelecendo, aliás, muitas regras materiais específicas sobre o tema.

Vejamos.

De acordo com a Constituição Federal, a União está proibida de tributar a renda das obrigações da dívida pública dos Estados, do Distrito Federal e dos Municípios (art. 151, II, da CF/88).

Os Poderes Legislativo, Executivo e Judiciário devem manter, de forma integrada, um sistema de controle interno com a finalidade de exercer o controle das operações de crédito, avais e garantias, bem como dos direitos e haveres da União (art. 74).

Ainda, a Constituição Federal proíbe “a realização de operações de créditos que excedam o montante das despesas de capital, ressalvadas as autorizadas mediante créditos suplementares ou especiais com finalidade precisa, aprovados pelo 
Poder Legislativo por maioria absoluta", bem como "a concessão ou utilização de créditos ilimitados" (art. 167, III e VII).

O Banco Central poderá comprar e vender títulos de emissão do Tesouro Nacional, com o objetivo de regular a oferta de moeda ou a taxa de juros (art. $164, \mathbb{} 2^{\circ}$.

Quando cuida da chamada política urbana, a Constituição Federal permite aos municípios que, por meio de lei específica para área incluída no plano diretor, exija, nos termos da lei federal, do proprietário do solo urbano não edificado, subutilizado ou não utilizado, que promova seu adequado aproveitamento, sob pena, sucessivamente, de parcelamento ou edificação compulsórios; imposto sobre a propriedade predial e territorial urbana progressivo no tempo; desapropriação. Esta última poderá ser paga com utilização de títulos da dívida pública emitidos após prévia aprovação pelo Senado Federal, "com prazo de resgate de até dez anos, em parcelas anuais, iguais e sucessivas, assegurados o valor real da indenização e os juros legais" (art. 182, $\mathbb{S} 4^{\circ}$ ).

De outra banda, tratando da política agrícola e fundiária, a Constituição Federal atribui à União a competência para desapropriar por interesse social, para fins de reforma agrária, o imóvel rural que não esteja cumprindo sua função social, e, para isso, autoriza a emissão de títulos públicos (dívida agrária) para realizar prévia e justa indenização, "com cláusula de preservação do valor real, resgatáveis no prazo de até vinte anos, a partir do segundo ano de sua emissão, e cuja utilização será definida em lei” (art. 184, "caput”). Para tanto, a lei orçamentária deverá fixar anualmente o volume total de títulos da dívida agrária, assim como o montante de recursos para atender ao programa de reforma agrária no exercício $\left(\operatorname{art} .184, \mathbb{S} 4^{\circ}\right)$.

Cuidando de regras para a Assistência Social, a Constituição Federal permite aos Estados e ao Distrito Federal vincular a programa de apoio à inclusão e promoção social até cinco décimos por cento de sua receita tributária líquida, mas proíbe a utilização de tais recursos para o pagamento de serviço da dívida (art. 204, $\mathbb{S}$ único).

Tratando do tema Cultura, a Constituição Federal traz algo semelhante ao permitir aos Estados e ao Distrito Federal vincular a fundo estadual de fomento à cultura até cinco décimos por cento de sua receita tributária líquida, para o financiamento de programas e projetos culturais, mas proibindo também a utilização de tais recursos para pagamento de serviço da dívida (art. $216, \mathbb{S} 6^{\circ}$ ).

A União é proibida de, direta ou indiretamente, assumir, em decorrência da criação de Estado, encargos referentes a despesas com pessoal inativo e com encargos e amortizações da dívida interna ou externa da administração pública, inclusive da indireta (art. 234). 
Quando a Constituição Federal instituiu o parcelamento de precatórios, autorizou às entidades devedoras que emitissem títulos de dívida pública não com-

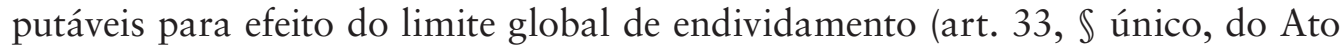
das Disposições Constitucionais Transitórias).

Após definir competências e estipular algumas regras específicas para a dívida pública, a Constituição Federal, em seu art. 163, determina que caberá à Lei Complementar tratar de alguns aspectos relevantes do tema, devendo dispor sobre finanças públicas; dívida pública externa e interna, incluída a das autarquias, fundações e demais entidades controladas pelo Poder Público; concessão de garantias pelas entidades públicas; sobre emissão e resgate de títulos da dívida pública; bem como sobre operações de câmbio realizadas por órgãos e entidades da União, dos Estados, do Distrito Federal e dos Municípios.

No âmbito da legislação ordinária, a Constituição Federal permite que a lei orçamentária anual trate da contratação de operações de crédito, ainda que por antecipação de receita (art. 165, $\mathbb{S} 8^{\circ}$ ).

Por outro lado, ainda que admitidas em geral, eventuais emendas ao projeto de lei do orçamento anual ou aos projetos que o modifiquem nunca poderão incidir sobre o "serviço da dívida" (art. 166, $\mathbb{S} 3^{\circ}, \mathrm{II}$, “b”).

Finalmente, destacamos que a Constituição, considerando os nefastos efeitos do não cumprimento das obrigações financeiras pelo Estado, determina que a falta de pagamento da dívida pública fundada (aquela com prazo de resgate superior a 12 meses) pode ensejar a drástica medida da intervenção. Há sutil diferença entre as hipóteses de intervenção federal e estadual:

a) intervenção federal (União nos Estados e no Distrito Federal). Requisitos: suspensão do pagamento da dívida fundada por mais de dois anos consecutivos, salvo motivo de força maior;

b) intervenção estadual (estados nos municípios). Requisitos: deixar de ser paga a dívida fundada por dois anos consecutivos, salvo motivo de força maior.

Assim, vemos que a Constituição Federal, em síntese, define princípios administrativos aplicáveis à dívida pública, fixa competências legislativas a respeito, estabelece regras de conduta diretamente ligadas a essa atividade, incluindo sanção extrema de intervenção para casos de descumprimentos, bem como deixa para leis complementares e ordinárias o complemento do sistema normativo respectivo.

Vejamos, então, o que a leis complementares dizem a respeito. 


\section{LEIS COMPLEMENTARES E A DÍVIDA PÚBLICA}

A Lei n. 4.320/64 foi recepcionada como lei complementar por nossa Constituição Federal de 1988, tratando de normas gerais de direito financeiro.

Logo em seu início $\left(\operatorname{art.} 3^{\circ}\right.$ ), determina que a Lei Orçamentária deverá prever todas as receitas, inclusive as decorrentes de operações de crédito autorizadas em lei, mas excepciona as operações de crédito por antecipação da receita, as emissões de papel-moeda e outras entradas compensatórias, no ativo e passivo financeiros. Aliás, diz expressamente que a Lei Orçamentária poderá autorizar o Executivo a "realizar em qualquer mês do exercício financeiro, operações de crédito por antecipação da receita, para atender a insuficiências de caixa" (art. 7. ${ }^{\circ}$ ). O produto estimado de operações de crédito e de alienação de bens imóveis poderá ser incluído na receita quando especificamente autorizadas pelo Poder Legislativo de forma que possa o Poder Executivo realizá-las no exercício (art. $7^{\circ}, \mathbb{S} 2^{\circ}$.

Além disso, essa Lei classifica como receitas de capital "as provenientes da realização de recursos financeiros oriundos de constituição de dívidas" (art. 11, $\mathbb{S} 2^{\circ}$ ) e como despesas de capital as utilizadas para amortização da dívida pública, definindo como despesas correntes os pagamentos de juros da dívida pública (art. 13).

Determina, ainda, que a "dívida flutuante" engloba os restos a pagar, excluídos os serviços da dívida; os serviços da dívida a pagar; os depósitos; e os débitos de tesouraria (art. 92).

Diz que a "dívida fundada compreende os compromissos de exigibilidade superior a doze meses, contraídos para atender a desequilíbrio orçamentário ou a financeiro de obras e serviços públicos", a qual deverá ser escriturada de forma a permitir identificar a "posição dos empréstimos, bem como os respectivos serviços de amortização e juros” (art. 98 e seu $\mathbb{\text { único). }}$.

Define que, no Balanço Patrimonial, o passivo financeiro deve compreender as dívidas fundadas e outras cujo pagamento independa de autorização orçamentária, mas também deve englobar o passivo permanente, que compreenderá as dívidas fundadas e outras que dependam de autorização legislativa para amortização ou resgate $\left(\operatorname{art.} 105, \mathbb{S} \mathbb{S} 3^{\circ}\right.$ e $\left.4^{\circ}\right)$.

Quanto à legislação ordinária (leis orçamentárias), determina que a proposta orçamentária que o Poder Executivo encaminhará ao Poder Legislativo deve conter "mensagem" que conterá, dentre outras coisas, uma "exposição circunstanciada da situação econômico-financeira, documentada com demonstração da dívida fundada e flutuante, saldos de créditos especiais, restos a pagar e outros compromissos financeiros exigíveis" (art. 22). 
Também estabelecendo normas gerais de finanças públicas, mas com foco na responsabilidade na gestão fiscal, a Lei Complementar n. 101/2000, conhecida como Lei de Responsabilidade Fiscal (LRF) traz importantes regras sobre a dívida pública.

Começa já dizendo que a responsabilidade fiscal pressupõe uma atuação planejada e transparente, sujeita “a limites e condições no que tange a renúncia de receita, geração de despesas com pessoal, da seguridade social e outras, dívidas consolidada e mobiliária, operações de crédito, inclusive por antecipação de receita, concessão de garantia e inscrição em Restos a Pagar” $\left(\operatorname{art.} 1^{\circ}, \mathbb{S} 1^{\circ}\right)$.

Após, a Lei de Responsabilidade Fiscal destina um amplo capítulo ao tema da dívida pública (arts. 29 a 42), tratando, inicialmente, de definições básicas a respeito para, após, cuidar dos limites dessa dívida, das operações de crédito e de suas garantias.

Nessa linha, a chamada Dívida Pública Consolidada ou Fundada - para a LRF é a soma do seguinte:

a) montante total das obrigações financeiras do ente federativo, assumidas em virtude de leis, contratos, convênios ou tratados e das operações de crédito, todas para amortização em prazo superior a doze meses;

b) operações de crédito de prazo inferior a 12 meses, mas cujas receitas tenham constado do orçamento;

c) emissão de títulos de responsabilidade do BACEN.

Esta definição legal de dívida pública consolidada ou fundada difere da classificação feita pela doutrina quanto ao prazo do débito público, distinguindo-o entre dívida flutuante e dívida fundada ou consolidada. Também modifica um pouco a definição de dívida fundada feita pela Lei n. 4.320/64.

Dívida pública mobiliária, de acordo com a LRF, é a representada por títulos emitidos pela União, incluindo os do BACEN, Estados e Municípios.

A LRF proíbe a contratação de operação de crédito entre um ente da Federação, diretamente ou por meio de fundo ou de sua administração indireta, salvo se realizada por instituição financeira estatal (discute-se a constitucionalidade do dispositivo diante da autonomia dos Estados/DF e Municípios, mas o STF tem entendido possível tal limitação pela LRF, cf. ADI-MC 2.250). Possível a aquisição de títulos da dívida pública da União pelos demais entes federativos.

Proibiu, ainda, a operação de crédito entre instituição financeira estatal e o ente federativo que a controla. 
Quanto aos restos a pagar, a LRF, para evitá-los no fim do mandato, determina que a partir de $10^{\circ}$ de maio do último ano do mandato não se pode contrair obrigação de despesa que:

a) não possa ser cumprida integralmente naquele ano;

b) tenha parcelas a serem pagas no exercício seguinte sem que haja suficiente disponibilidade de caixa para tanto.

Para permitir um melhor controle das contas públicas, a LRF determina que o projeto de lei de diretrizes orçamentárias deve ter um "Anexo de Metas Fiscais", no qual serão estabelecidas metas anuais, em valores correntes e constantes, relativas a receitas, despesas, resultados nominal e primário e montante da dívida pública, para o exercício a que se referirem e para os dois seguintes $\left(\operatorname{art} .4^{\circ}, \mathbb{S} 1^{\circ}\right)$.

Quanto à Lei Orçamentária Anual, a LRF diz que todas as despesas relativas à dívida pública, mobiliária ou contratual, e as receitas que as atenderão, constarão dela. Já eventual refinanciamento da dívida pública constará separadamente na lei orçamentária e nas de crédito adicional. Define que a atualização monetária do principal da dívida mobiliária refinanciada não poderá superar a variação do índice de preços previsto na lei de diretrizes orçamentárias, ou em legislação específica (art. $\left.5^{\circ}, \mathbb{S} \mathbb{S}\right)$.

De acordo com a LRF (art. 30), o Presidente da República deve encaminhar propostas para fixação de limites para a dívida pública, sendo ao:

I - Senado Federal: proposta de limites globais para o montante da dívida consolidada da União, Estados e Municípios, cumprindo o que estabelece o inciso VI do art. 52 da Constituição, bem como de limites e condições relativos aos incisos VII, VIII e IX do mesmo artigo;

II - Congresso Nacional: projeto de lei que estabeleça limites para o montante da dívida mobiliária federal a que se refere o inciso XIV do art. 48 da Constituição, acompanhado da demonstração de sua adequação aos limites fixados para a dívida consolidada da União, atendido o disposto no inciso I do $\mathbb{S} 1^{\circ}$ deste artigo.

Destaque-se que a LRF criou regra importante para o controle da dívida pública ao definir que "os precatórios judiciais não pagos durante a execução do orçamento em que houverem sido incluídos integram a dívida consolidada, para fins de aplicação dos limites” ( $\mathbb{S} 7^{\circ}$ do art. 30).

A LRF veda operação entre entes de nível diverso (excetuam-se desta vedação as operações entre instituição financeira estatal e outro ente da Federação, inclusive suas entidades de administração indireta, que não se destinem a finan- 
ciar, direta ou indiretamente, despesas correntes; refinanciar dívidas não contraídas junto à própria instituição concedente; a vedação da LRF não impede Estados e Municípios de comprar títulos da dívida da União como aplicação de suas disponibilidades).

Veda, também, a realização de operação com ente controlado.

De outra banda, a LRF equipara a operações de crédito e veda: a) a captação de recursos a título de antecipação de receita de tributo ou contribuição cujo fato gerador ainda não tenha ocorrido; b) o recebimento antecipado de valores de empresa em que o Poder Público detenha direta ou indiretamente, a maioria do capital social com direito a voto, salvo lucros e dividendos, na forma da legislação; c) a assunção direta do compromisso, confissão de dívida ou operação assemelhada, com fornecedor de bens, mercadorias ou serviços, mediante emissão, aceite a aval de título de crédito, não se aplicando esta vedação a empresas estatais dependentes; d) a assunção de obrigação, sem autorização orçamentária, com fornecedores para pagamento a posteriori de bens e serviços.

De acordo com a LRF, o Ministério da Fazenda verificará o cumprimento dos limites e condições relativos à realização de operações de crédito de cada ente da Federação, inclusive das empresas por eles controladas, direta ou indiretamente.

Ademais, sem prejuízo das atribuições do Senado Federal e do Banco Central do Brasil, o Ministério da Fazenda efetuará o registro eletrônico centralizado e atualizado das dívidas públicas interna e externa, garantido o acesso público às informações, que incluirão encargos e condições de contratação, bem como saldos atualizados e limites relativos às dívidas consolidada e mobiliária, operações de crédito e concessão de garantias.

A instituição financeira que contratar operação de crédito com ente da Federação, exceto quando relativa à dívida mobiliária (representada por títulos emitidos pela União, Estados e Municípios) ou à externa, deverá exigir comprovação de que a operação atende as condições e limites estabelecidos.

A operação realizada com a infração do disposto na LRF será considerada nula, procedendo-se ao seu cancelamento, mediante a devolução do principal, vedados o pagamento de juros e demais encargos financeiros. Se a devolução não for efetuada no exercício de ingresso dos recursos, será consignada reserva específica na lei orçamentária para o exercício seguinte.

No mais, as garantias em operações de crédito internas e externas prestadas por um ente da Federação a outro está condicionada ao oferecimento de contragarantia em valor igual ou superior ao da garantia.

As entidades da administração indireta, inclusive suas empresas controladas e subsidiárias, não poderão conceder garantia, com exceção da garantia de em- 
presa controlada à subsidiária ou controlada sua, ou a garantia prestada por instituição financeira à empresa nacional.

Essa proibição não se aplica à garantia prestada (i) por instituições financeiras estatais, e (ii) pela União a empresas de natureza financeira por ela controladas, direta e indiretamente, quanto a operações de seguro de crédito à exportação.

A Lei Complementar n. 148/2014 alterou a LRF, dispondo sobre critérios de indexação dos contratos de refinanciamento da dívida celebrados entre a União, Estados, o Distrito Federal e Municípios, e dando outras providências.

Verifica-se, assim, uma preocupação muito grande da legislação complementar em fazer definições e estabelecer regras de controle, de transparência e de organização do endividamento público.

\section{LEIS ORDINÁRIAS}

De acordo com a Constituição Federal, cabe à lei ordinária, em matéria de dívida pública, essencialmente dispor sobre políticas de crédito (art. 22, VII), leis orçamentárias (plano plurianual, lei de diretrizes orçamentárias e lei orçamentária anual), bem como sobre o montante da dívida mobiliária federal (art. 48, XIV).

Em verdade, observa-se que a própria Constituição Federal e suas leis complementares abrangem muito da regulamentação da dívida pública, sendo menor a relevância das leis ordinárias neste tema.

Como leis ordinárias federais que tratam do assunto, podemos citar a Lei n. 9.496/97, que estabeleceu critérios para a consolidação, a assunção e o refinanciamento, pela União, da dívida pública de responsabilidade dos Estados e do Distrito Federal; e a Lei n. 10.179/2001, que dispõe sobre os títulos da dívida pública de responsabilidade do Tesouro Nacional, consolidando a legislação em vigor sobre a matéria.

No entanto, são as leis de diretrizes orçamentárias e as leis orçamentárias anuais, que, como leis ordinárias, mais tratam da dívida pública em nosso ordenamento.

Há, de outro lado, uma outra importante fonte normativa em matéria de dívida pública no Brasil: as normas infralegais.

\section{NORMAS INFRALEGAIS}

Vejamos as diversas normas infralegais que cuidam do endividamento público no Brasil

O Senado Federal editou uma série de resoluções a respeito. 
Atualmente, a Resolução SF n. 48/2007 é que dispõe sobre os limites globais para as operações de crédito externo e interno da União, de suas autarquias e demais entidades controladas pelo poder público federal e estabelece limites e condições para a concessão de garantia da União em operações de crédito externo e interno.

Em linhas gerais, apresenta algumas definições, cuida de vedações expressas, impõe limites e condições para a realização de operações de crédito, bem como para prestação de garantias pelo Poder Público.

Dentre as definições, diz que operações de crédito, para os efeitos desta Resolução, são “os compromissos assumidos com credores situados no país ou no exterior, em razão de mútuo, abertura de crédito, emissão e aceite de título, aquisição financiada de bens, recebimento antecipado de valores provenientes da venda a termo de bens e serviços, arrendamento mercantil e outras operações assemelhadas, inclusive com o uso de derivativos financeiros" (art. $3^{\circ}$ ).

Ficam ainda equiparadas às operações de crédito:

I - recebimento antecipado de valores de empresa em que o Poder Público detenha, direta ou indiretamente, a maioria do capital social com direito a voto, salvo lucros e dividendos, na forma da legislação;

II - assunção direta de compromisso, confissão de dívida ou operação assemelhada, com fornecedor de bens, mercadorias ou serviços, mediante emissão, aceite ou aval de títulos de crédito;

III - assunção de obrigação, sem autorização orçamentária, com fornecedores para pagamento a posteriori de bens e serviços $\left(\operatorname{art} .3^{\circ}\right)$.

Dentre as vedações impostas à União, destacam-se: a do o recebimento antecipado de valores de empresa em que o Poder Público detenha, direta ou indiretamente, a maioria do capital social com direito a voto, salvo lucros e dividendos, na forma da legislação; a da assunção direta de compromisso, confissão de dívida ou operação assemelhada, com fornecedor de bens, mercadorias ou serviços, mediante emissão, aceite ou aval de títulos de crédito, não se aplicando esta vedação a empresas estatais dependentes; da assunção de obrigação, sem autorização orçamentária, com fornecedores para pagamento a posteriori de bens e serviços; e a da concessão de qualquer subsídio ou isenção, redução da base de cálculo, concessão de crédito presumido, incentivos, anistias, remissão, reduções de alíquotas e quaisquer outros benefícios tributários, fiscais ou financeiros, não autorizados na forma de lei específica que regule exclusivamente as matérias retroenumeradas ou o correspondente tributo ou contribuição $\left(\operatorname{art.~} 5^{\circ}\right)$.

Quanto aos limites para a realização de operações de crédito interno e externo, a União não poderá realizá-las em nível superior a $60 \%$ (sessenta por cento) da sua receita corrente líquida e o montante da sua dívida consolidada não pode- 
rá exceder o teto estabelecido pelo Senado Federal, conforme o disposto em resolução específica.

Tratando-se de operações de crédito externo, estão estas sujeitas à aprovação específica do Senado Federal, excluído o Banco Central do Brasil, bem como as garantias concedidas pela União a operações de mesma natureza, inclusive aditamento a contrato relativo à operação de crédito externo que preveja a elevação dos valores mutuados ou financiados ou a redução dos prazos de pagamento.

No que pertine às garantias concedidas pela União, não poderão superar $60 \%$ (sessenta por cento) da sua receita corrente líquida.

O Tesouro Nacional é quem emite os títulos públicos. Isso é feito por ofertas públicas competitivas (leilões) com a participação direta de instituições financeiras, mas também por meio de emissões diretas para finalidades específicas, definidas em leis (emissões não competitivas) ou por vendas diretas a pessoas físicas, por meio do Programa Tesouro Direto.

Ademais, a Secretaria do Tesouro Nacional é quem publica o chamado "Manual de Contabilidade Aplicado ao Setor Público", que é imposto à União, Estados, Distrito Federal e Municípios (Portaria Conjunta STN/SOF n. 02, de 22 de dezembro de 2016; Portaria STN n. 840, de 21 de dezembro de 2016), cujos objetivos são:

a) aprimorar os critérios de reconhecimento de despesas e receitas orçamentárias;

b) instituir instrumento eficiente de orientação comum aos gestores nos três níveis de governo, mediante consolidação, em um só documento, de conceitos, regras e procedimentos de reconhecimento e apropriação das receitas e despesas orçamentárias;

c) elaborar demonstrativos de estatísticas de finanças públicas em consonância com os padrões e regras estabelecidas nos acordos e convênios internacionais de que a União for parte;

d) proporcionar maior transparência sobre as contas públicas e uniformizar a classificação das receitas e despesas orçamentárias.

Portanto, verifica-se que as normas infralegais também possuem um papel importante no sistema normativo da dívida pública no Brasil, tornando-o complexo e de difícil compreensão em sua totalidade.

\section{CONCLUSÕES}

Um Estado Democrático de Direito deve ter como fundamento e objetivo o cumprimento integral de seu próprio sistema normativo, sendo então inconcebí- 
vel o desconhecimento de normas, principalmente referentes ao controle dessa importante atividade financeira ligada à dívida pública.

Nesse contexto, vimos que a Constituição Federal e as leis complementares no Brasil contemplam a maioria das normas aplicáveis ao endividamento público, ficando papel reduzido nesta seara para as leis ordinárias e para as normas infralegais.

Não obstante, há uma quantidade muito grande de normas a respeito da dívida pública no Brasil e todas pulverizadas em órgãos de diferentes níveis e de distintos entes federativos (lembre-se de que leis ordinárias poderão existir também no âmbito dos estados e dos municípios).

Assim, o conhecimento da matéria para a população em geral, mas também para leitores especializados não é tarefa fácil, dificultando o controle, o acompanhamento e mesmo o aperfeiçoamento dessa atividade que, como visto, movimenta trilhões de reais em nosso país.

Por isso, na esteira do que se observa com o "Manual de Contabilidade Aplicado ao Setor Público", evidencia-se a necessidade de uma organização mais eficiente e transparente da matéria, que poderia ser condensada em verdadeiro código específico em cada ente federativo dentro de suas competências constitucionais.

Afinal, condensar as normas aplicáveis à dívida pública em poucos instrumentos é medida importante para uma melhor compreensão da matéria, mas também para um controle técnico e social mais efetivo e para facilitar o aperfeiçoamento constante das normas com menos riscos de incongruências e incompatibilidades entre elas.

Já é tempo do tema ser tratado com mais sistematização e seriedade em nosso país.

\section{REFERÊNCIAS}

ABRAHAM, Marcus. Lei de Responsabilidade Fiscal Comentada. 2 ed. São Paulo: Ed. Forense, 2005.

ANDRADE, Cesar Augusto Seijas de. O Controle do Endividamento Público e a Autonomia dos Entes da Federação. Dissertação (Mestrado em Direito Econômico e Financeiro). Faculdade de Direito, Universidade de São Paulo, São Paulo, 2012.

ASSONI FILHO, Sérgio. Crédito público e responsabilidade fiscal. Porto Alegre: Núria Fabris Editora, 2007.

ATALIBA, Geraldo. Empréstimos públicos e seu regime jurídico. Editora Revista dos Tribunais, 1973.

BRANDÃO, Carlos. Fórum sobre a Dívida Pública - Resumo de sua Conjuntura Atual. Revista Tributária e de Finanças Públicas | vol. 18/1997 | p. 301-304 | JanMar./1997. 
CONTI, José Mauricio. Devo, não nego: o Direito Financeiro e o dilema da dívida pública. Conjur, 17/10/2017. In: https://www.conjur.com.br/2017-out-17/contas-vistadevo-nao-nego-direito-financeiro-dilema-divida-publica\#author.

CONTI, José Mauricio. Direito Financeiro na Constituição de 1988. São Paulo: Oliveira Mendes, 1988.

CONTI, José Mauricio. Federalismo fiscal e fundos de participação. São Paulo: Juarez de Oliveira, 2001.

CONTI, José Mauricio; SCAFF, Fernando Facury. (Coord.). Orçamentos Públicos e Direito Financeiro. São Paulo: RT, 2011.

CONTI, José Mauricio; SCAFF, Fernando Facury; BRAGA, Carlos Eduardo Faraco (orgs.). Federalismo fiscal: questões contemporâneas. Florianópolis: Conceito Editorial, 2010.

CORIGLIANO, Rogério de Menezes. Empréstimos públicos. São Paulo: FDUSP (Dissertação de Mestrado), 2003.

DARÓS, Leandro Luís; PEREIRA, Adriano de Souza. Análise das normas brasileiras de contabilidade aplicadas ao setor público-NBCASP: mudanças e desafios para a contabilidade pública. In: Congresso USP de Iniciação Científica, 2009.

FURTADO, J. R. Caldas. Elementos de Direito Financeiro. Belo Horizonte: Fórum, 2009.

HARADA, KIYOSHI. Responsabilidade Fiscal. São Paulo: Juarez de Oliveira, 202.

LEITE, Marcel Guedes; ARVATE, Paulo Roberto. Uma visão institucional para a dívida pública no Brasil. Revista de Economia Política, v. 22, n. 4, p. 88, 2002.

LIMA, Gerson P. Dívida Pública: a Intervenção Permanente do Estado na Economia. Revista Tributária e de Finanças Públicas I vol. 12/1995 | p. 236-242 | Jul.-Set. 1995.

LOCHAGIN, Gabriel Loretto. A flexibilidade da execução orçamentária. 2012. Dissertação (Mestrado em Direito Econômico e Financeiro). Faculdade de Direito, Universidade de São Paulo, São Paulo, 2012.

LOCHAGIN, Gabriel Loretto. Elementos Jurídicos da Reestruturação Internacional da Dívida Pública. Tese (Doutorado em Direito Econômico e Financeiro). Faculdade de Direito, Universidade de São Paulo, São Paulo, 2016.

MARTINS, Ives Gandra da Silva. Os Fundamentos Constitucionais da Lei de Responsabilidade Fiscal n 101/2000. In: ROCHA, Valdir de Oliveira. Aspectos Relevantes da Lei de Responsabilidade Fiscal. São Paulo: Dialética, 2001.

MENDONÇA, Félix. A dívida pública brasileira. Relator Deputado Félix Mendonça; equipe técnica: Consultor Legislativo César Costa Alves de Mattos, coordenador, Consultor Legislativo Alberto Pinheiro de Queiroz Filho, Consultor Legislativo Edilberto Carlos Pontes Lima. - Brasília: Câmara dos Deputados, Coordenação de Publicações, 2005.

OLIVEIRA, Regis Fernandes de. Curso de Direito Financeiro. São Paulo: Editora Revista dos Tribunais, 2006. 
PINTO, Élida Graziane. Controle da Administração do Endividamento Público. Belo Horizonte: UFMG (Tese de Doutorado), 2006.

SADDI, Jairo. Alguns Aspectos Legais e Históricos do Financiamento da Dívida Pública no Brasil. Revista Tributária e de Finanças Públicas | vol. 17/1996 | p. 230-235 | Out-Dez/1996.

SADDY, André. Lei de responsabilidade fiscal e democratização da gestão pública. Jus navigandi, 2002.

SILVA, Anderson Caputo.; CARVALHO, Lena O.; MEDEIROS, Otávio L. (Orgs.). Divida Pública: a experiência brasileira. Brasília: Secretaria do Tesouro Nacional/ Banco Mundial, 2009.

TORRES, Heleno T. Direito Constitucional Financeiro. Teoria da Constituição Financeira. São Paulo: RT, 2014.

TORRES, Ricardo Lobo. Curso de Direito Financeiro e Tributário. Rio de Janeiro: Renovar, $14^{a}$ ed., 2007.

\section{Sítios na internet}

http://www.portal.tcu.gov.br/comunidades/macroavaliacao-governamental/areas-deatuacao/divida-publica/

http://www.bcb.gov.br/htms/infecon/finpub/default.asp

http://www.tesouro.fazenda.gov.br/divida-publica-federal 
